FACTA UNIVERSITATIS

Series: Physical Education and Sport, Vol. 16, No 2, 2018, pp. 281 - 296

https://doi.org/10.22190/FUPES180925025I

Narrative review article

\title{
PHYSICAL ACTIVITY AS A PRE-ANALYTICAL FACTOR AFFECTING LABORATORY TEST RESULTS
}

\author{
UDC 796.577
}

\author{
Aleksandra Isaković ${ }^{1}$, Goran Janković ${ }^{2}$, Sanja Mazić $^{3}$, \\ Željka Stanojević ${ }^{1}$, Dejan Nešić ${ }^{3}$ \\ ${ }^{1}$ Institute of Medical and Clinical Biochemistry, Faculty of Medicine, \\ University of Belgrade, Belgrade, Serbia \\ ${ }^{2}$ Faculty of Sport and Physical Education, University of Belgrade, Belgrade, Serbia \\ ${ }^{3}$ Department of Medical Physiology, Faculty of Medicine, University of Belgrade, \\ Belgrade, Serbia
}

\begin{abstract}
It is known that physical activity undoubtedly exhibits positive effects, decreasing the incidence of many chronic diseases. But, at present, physical activity is consider a pre-analytical factor/error related to the sampling process. Namely, different types of physical activity as well as its different intensity may influence a broad array of laboratory variables. The amount of extracellular release and clearance from blood of most of these biomarkers is markedly influenced by the biological characteristics of the molecule(s), level of training, type, intensity and duration of exercise, and time of recovery after training. It is therefore noteworthy to have the anamnestic information about these specific characteristics of physical activity and to understand the "physiologic" effects of exercise on laboratory results and when the threshold to pathological effects has been crossed. There are a lot of research data about the influence of physical activity on laboratory test results, but the accessible results are scattered and inconsistent since variations in type, duration, and intensity of exercise, sample size, and biological, behavioral, and experimental variables are not always adequately controlled. In this study we put an effort to summarize the most often changes in laboratory results that occur as a result of physical activity and to explain these changes in accordance with their biochemical, physiological and metabolic features.
\end{abstract}

Key words: exercise, biomarkers, metabolism, serum enzymes, laboratory test results

Received September 25, 2018 / Accepted October 2, 2018

Corresponding author: Aleksandra Isaković

Institute of Medical and Clinical Biochemistry, Faculty of Medicine, University of Belgrade,

Dr Subotića 8, 11000 Belgrade, Serbia

Phone: +381 $113636300 •$ E-mail: aleksandra.isakovic@ med.bg.ac.rs 


\section{THEORETICAL CONSIDERATIONS OF THE PROBLEM}

In recent years, different pre-analytical factors affecting the values of laboratory results were investigated. Those factors can be classified as physiological, factors related to the sampling process and interfering factors. Physical activity belongs to pre-analytical factors related to the sampling process (Sanchis-Gomar \& Lippi, 2014).

Physical activity is defined as any bodily movement produced by skeletal muscle that requires energy expenditure (Caspersen, Powell, \& Christenson, 1985). It is well known that physical activity, undoubtedly, displays a positive effect on laboratory test results as well as in clinical manifestations in many chronic non-infective diseases such as cardiovascular disease, hypertension, obesity, diabetes mellitus and dyslipoproteinemia. On the other hand, depending on its type, frequency and intensity, physical activity can affect specific laboratory test results. Namely, physical activity increases expenditure of intracellular ATP which may induce the loss of plasma membrane integrity and, as a consequence, the outflow of intracellular content. That way, the activity of different non-functional plasma enzymes, such as aspartate aminotransferase (AST), alanine aminotransferase (ALT), creatine kinase (CK), can increase in plasma after physical activity of specific intensity and duration, depending also on the pre-exercise characteristics of the individual. At the same time, increased oxidation of fatty acids, and glucose uptake into the cells during physical activity can, on their part, positively affect the circulating levels of glucose, triacylglycerols, cholesterol, low density (LDL) and high density (HDL) lipoproteins. Physical activity can also affect kidney function that can be followed through changes in both plasma and urine.

Therefore, it is important to define the cut-off value between "physiological" and "pathological" changes of laboratory parameters that occur as a result of physical activity which would help in a more objective interpretation and, eventually continuation with additional medical investigations, if necessary (Foran, Lewandrowski, \& Kratz, 2003).

For that reason, together with the information about the intensity, duration and frequency of the performed physical activity, it is important for a physician to understand the "physiologic" effects of exercise on laboratory results and when the threshold to pathological effects has been crossed.

There are a lot of research data about the influence of physical activity on laboratory test results, but the accessible literature data are often contradictory due to the variations in type, duration, and intensity of exercise implemented in investigations, sample size, and biological, behavioral, and experimental variables that are not always adequately controlled. In this study we made an effort to summarize the most frequent changes in laboratory test results that occur as a result of physical activity and to explain these changes in accordance with their biochemical, physiological and metabolic features.

\section{The main laboratory parameters affected by physical activity}

An underappreciated primary cause of most chronic diseases is the lack of sufficient daily physical activity ("physical inactivity") (Booth, Roberts, \& Laye, 2012). Disturbance in lipid metabolism and diabetes mellitus type 2 are most often presented in the general population (Mooradian, 2009). 


\section{Physical activity and lipid profile}

Dyslipoproteinemia affecting endothelial function is the basic risk factor for cardiovascular disease. Physical activity helps better control of the lipid level not only through body weight control but also the activation of enzymes involved in cholesterol elimination out of the cell as well activation of enzymes that increase low density lipoprotein (LDL) degradation and backward cholesterol transport in the liver within high density lipoprotein (HDL) particles (Durstine \& Haskell, 1994). Thus, physical activity activates lipoprotein lipase (LPL), lecithin cholesterol acyl transferase (LCAT) and cholesterol ester transfer protein (CETP), all of them responsible for increased HDL synthesis and cholesterol transport in the liver (Mann, Beedie, \& Jimenez, 2014). Once the cholesterol reaches the hepatocytes, it serves as the precursor for bile acid synthesis and is no longer considered a risk factor for atherosclerosis. This beneficial effect of physical activity on cholesterol metabolism depends on the exercise intensity. While some studies defined, as cardio protective, a physical activity of 6 and more MET (21 $\mathrm{ml} / \mathrm{kg}$.min) (Lakka \& Salonen, 1992; Seip et al., 1993) other studies showed that a further increase of physical activity to more than 6 MET does not additionally increase HDL synthesis (Leclerc, Allard, Talbot, Gauvin, \& Bouchard, 1985). The best results for the female population were observed with a middle intensity exercise program which mostly affected HDL synthesis even better than an intensive exercise program (Duncan, Gordon, \& Scott, 1991; Spate-Douglass \& Keyser, 1999; Santiago, Leon, \& Serfass, 1995). But in the postmenopausal period, more intensive continuous exercise of at least $75 \% \mathrm{HRmax}$ is required to achieve the same beneficial effect (Lindheim et al., 1994).

When discussing whether intensity or duration of physical activity affects cholesterol metabolism more, the general conclusion was that weekly energy expenditure is most important factor in both, the male and female population, and that every increase in HDL synthesis depends on the duration, frequency and exercise intensity, as well as the initial pre-exercise HDL concentration (Vella, Kravitz \& Janot, 2001).

\section{Physical activity and glycemia regulation}

Physical activity leads to a decrease in body weight and visceral adipose tissue and, at the same time, increases insulin sensitivity and leads to a transitory decrease in glycemia (Albright et al., 2000). This effect is additionally potentiated with increased glucose uptake into muscle and adipose tissue since aerobic and anaerobic exercise increase GLUT4 expression via insulin independent pathways which include changes in intracellular level of calcium ions, AMP-dependent protein kinase (AMPK) activity and nitrogen oxide (NO) production (Richter \& Hargreaves, 2013).

Beside morning blood sugar concentration, another biochemical marker of glycemia regulation is glycosylated hemoglobin, HbAlc. As the life span of erythrocyte is approximately 120 days, the concentration of $\mathrm{HbAlc}$ is used to estimate the average glycemia during the last 2-3 months period (Yavari et al., 2011). Together with morning blood sugar level, HbA1c is most often determined biochemical parameter in patients with Diabetes Mellitus (DM). Both intensity and duration of physical activity can affect $\mathrm{HbA1c}$ level while aerobic exercise or resistance training can modulate glycemia equally as oral antidiabetogenic drugs (Eriksson et al., 1997). In comparison to physically inactive persons, continuous exercise leads to a decrease of the body mass index (BMI), 
glycemia and concentration of $\mathrm{HbA} 1 \mathrm{c}$ and increase of $\mathrm{VO}_{2} \mathrm{max}$ (which is expected to be lower in patients with DM) (Najafipour et al., 2017). Therefore, the recommendation is that patients with DM should be physically active for at least 12 months. $\mathrm{VO}_{2} \max$ correlates well with insulin sensitivity and is usually decreased in patients with DM type 2 (Albright et al., 2000). Therefore, the goal of physical activity implementation to patients with DM type 2 is to increase their insulin sensitivity that would lead to better glycemia regulation. For the majority of patients, it is optimal to perform moderate/aerobic physical activity (50\% - 70\% HRmax) as, for example fast walking because it will increase translocation of GLUT4 transporters on the miocytes plasma membrane and, as a consequence, increase the uptake of glucose. But, moderate exercise that lasts longer than $2 \mathrm{~h}$ will increase secretion of catecholamine and others "diabetogenic" hormones, that would increase blood sugar level. Therefore, during this type of physical activity it is important to perform individual glucose measurements (Bweir et al., 2009) throughout the exercise program. This increase in glucose de novo synthesis is a result of a decreased insulin level which sensitizes hepatocytes to glucagon and therefore induces gluconeogenesis and glycogen degradation.

Thanks to this precise hormone regulation of glucose synthesis and its uptake, we do not expect any disturbances in regulation of glycemia in healthy persons engaged in physical activity. On the other hand, exercise helps better tolerance to increased glycemia in DM type 2 patients by increasing insulin sensitivity.

\section{Physical activity and liver tests}

Numerous biochemical tests are used for biochemical assessment of liver function (AST and ALT) biliary obstruction (alkaline phosphatase, bilirubin, gamma-glutamyl transferase, GGT) and synthetic liver function (plasma protein concentration) (Panteghini $\&$ Bais, 2001).

Hepatocytes destruction is usually monitored by measurement of alanine (ALT) and aspartate aminotransferase (AST) activity. But, those non-functional plasma enzymes are presented not only in the liver tissue but also in other tissues (Table 1).

Table 1 AST and ALT activity in different tissues relative to their activity in serum (adopted and modified from Panteghini \& Bais, 2001)

\begin{tabular}{lrr}
\hline Tissue & AST & ALT \\
\hline Heart & 7800 & 450 \\
Liver & 7100 & 2850 \\
Skeletal muscles & 5000 & 300 \\
Kidney & 4500 & 1200 \\
Pancreas & 1400 & 130 \\
Spleen & 700 & 80 \\
Lung & 50 & 45 \\
Erythrocytes & 15 & 7 \\
Serum & 1 & 1 \\
\hline
\end{tabular}

While AST activity is around 10 times greater in muscle than in the liver (Table 1), AST is even more predictable for myocyte necrosis (e.g. acute myocardial infarction, AMI) (Lofthus, Stevens, Armstrong, Granger, \& Mahaffey, 2012). In comparison with 
AST, ALT is a more specific marker of liver injury. Therefore, increase in aminotransferase plasma activity induced by physical activity does not absolutely indicate a liver injury (Panteghini \& Bais, 2001).

An increase in AST and ALT activity is expected after intensive physical activity such as a marathon race and/or endurance exercise. The AST and ALT activity as well as creatine kinase (CK) activity and myoglobine concentration can remain elevated during 710 days after exercise. Since AST alters in parallel with CK, this suggests an extrahepatic origin of AST (Weibrecht, Dayno, Darling, \& Bird, 2010). This theory is further confirmed with the fact that an increase in AST activity is not followed by an increase in GGT and/or alkaline phosphatase activity as a more specific marker of liver tissue injury (Pettersson et al., 2008).

On the other hand, an increase in ALT is obtained less frequently (in 75\%), and does not follow changes in CK activity. That is why an increase in ALT activity is not completely understood. A possible explanation is that ALT has a hepatic origin since, during rhabdomyolysis, a lot of different compounds are detoxicated and inactivated in liver (e.g. myoglobine) which can initiate hepatocyte necrosis (Vanholder, Sever, Erek, \& Lameire, 2000).

Given that increased activity of AST and ALT can be seen up to 7 days after physical activity (lifting weights) it is suggested that physical activity have to be excluded for at least 7 days before biochemical laboratory examination (Pettersson et al., 2008). If an additional physical activity is performed during those 7 days that will induce additional increase in AST and ALT activity (Sjogren, 2007). Therefore, if an increase in AST and ALT activity persists more than 7 days, this finding is considered pathological. When AST and CK activity increases simultaneously, the physician has to consider a possible AMI. Asymptomatic post-exercise increase in AST and ALT activity reaching values 1-2 times higher than the maximal reference one is clinically acceptable.

Physical activity also affects bilirubin concentration. It was shown that bilirubin concentration can increase after continuous physical activity of at least 6 months (3-4 times per week) and that its concentration is inversely related to the amount of adipose tissue, before and after exercise (Swift, Johannsen, Earnest, Blair, \& Church, 2012). It is believed that an increase in bilirubin concentration is a result of increased heme oxygenase activity or increased heme catabolism during exercise induced hemolysis. This increase in bilirubin concentration is considered a positive effect of physical activity since lower bilirubin concentration correlates with a higher risk of cardiovascular diseases. This protective effect of bilirubin can be attributed to antioxidative capacity of unconjugated bilirubin (Ziberna, Martelanc, Franko, \& Passamonti, 2016; Jansen \& Daiber, 2012) as well as its complementary activity with glutathione, the strongest endogenous antioxidant (Sedlak et al., 2009).

Together with AST and ALT, alkaline phosphatase (ALP) belongs to non-functional plasma enzymes. This enzyme is presented in four isozyme forms, one of them being tissue non-specific (found in the liver, bone and kidneys). Physical activity induces an increase in ALP that does not derive from the liver, but from bone tissue. Together with osteocalcin, bone ALP belongs to the markers of bone synthesis. Activity of this bone ALP isozyme can increase after 2 months of continuous physical activity and it is more sensitive to aerobic exercise. In non-trained individuals, the change in bone ALP activity depends on the duration of exercise while in well-trained individuals its increase depends 
more on exercise intensity (Banfi, Lombardi, Colombini, \& Lippi, 2010). An increase in bone ALP activity after a marathon race is expected to normalize during the following 24 hours (Crespo et al., 1999). Anaerobic training with resistance can also increase ALP activity during and after exercise (Fujimura et al., 1997) and since bone ALP is involved in the bone remodeling process, physical activity is therefore recommended in the prevention of osteoporosis. Short aerobic exercise, like running on an ergometer or short jogging (40 min) will induce an increase in bone ALP but, since those changes tend to normalize after 20 minutes, they do not affect the interpretation of laboratory results (Rudberg, Magnusson, Larsson, \& Joborn, 2000).

Liver synthetic capacity can be estimated via measurement of plasma protein concentration as all of them, except gamma globulins, are synthesized in the liver. But, no connection was observed between physical activity and de novo protein synthesis in the liver, except in fibronectin synthesis during and after physical activity (Carraro et al., 1990). Still, after physical activity, depending on its duration and intensity, some changes in total plasma protein concentration can be noticed. As these changes are not related to protein de novo synthesis in the liver, that means that hypoproteinemia or hypoalbuminemia can occur as the result of protein loss via urine (kidney dysfunction). On the other hand, hyperproteinemia is interpreted not as the result of de novo protein synthesis in the liver but as a consequence of dehydration during and after exercise - relative hyperproteinemia (Foran et al., 2003). By evidence, physical activity affects the concentration of plasma proteins that belong to acute phase reactants. During a marathon race, potential rhabdomyolysis and neuroendocrine stress stimulate IL-6 secretion that further stimulates the synthesis of acute phase reactants in the liver which is manifested mostly as an increase in CRP plasma concentration. This mechanism also prevents accumulation of toxic ammonia which is intensively released from muscle during muscle contractions as the result of amino acid catabolism (Carraro et al., 1990).

In conclusion, even all of the previously mentioned biomarkers originate from the liver only an increase in ALT and bilirubin can suggest liver injury, while an increase in AST and ALP activity suggests muscle injury and a bone remodeling process, respectively.

\section{Physical activity and biomarkers of kidney function}

In laboratory practice, kidney function is usually estimated by measuring urea and creatinine concentration and by calculation of creatinine clearance. Both urea and creatinine are excreted by urine. Under physiological conditions, a daily synthesized creatinine concentration depends primarily on muscle mass while urea concentration depends mainly on protein intake. Therefore, creatinine is routinely used as an endogenous marker of kidney function (Delaney, Price \& Lamb, 2001).

It was found that physical activity of moderate or high intensity can increase both, urea and creatinine (Hammouda et al., 2012; Mohseni et al., 2011) plasma concentration as well as decrease creatinine clearance, whereby these changes are normalized during the first 24h post-exercise (Calles-Escandon et al., 1984).

Kidney function can be estimated not only by a specific plasma analysis but also by analysis of urine and, for that reason, proteinuria and hematuria are recognized as markers of kidney dysfunction.

Normally, less than $150 \mathrm{mg}$ of albumins are excreted daily. Prevalence of proteinuria is $18 \%$ to $100 \%$ depending on the type and intensity of physical activity. It is very important to 
notify that physical activity affects proteinuria in patients with nephropathy as well as in patients with kidney transplants (Saeed, Pavan, Devaki, Mahendrakar, \& Holley, 2012).

The intensity of physical activity affects proteinuria more than the duration of physical activity. Moderate exercise can induce glomerular proteinuria with increased glomerular filtration of albumin while high intensity exercise will increase glomerular filtration of low molecular weight proteins, resulting in tubular proteinuria. Therefore, we can assume that proteinuria induced by physical activity has both a glomerular and tubular component (Heathcote, Wilson, Quest, \& Wilson, 2009). This exercise-induced proteinuria depends on the renine-angiotensine system and prostaglandins (Saeed et al., 2012) since the application of ACE inhibitors significantly decrease it. Also, increase in lactate concentration contributes to proteinuria because it induces changes in plasma protein conformation (Heathcote, Wilson, Quest, \& Wilson, 2009) that can promote their glomerular filtration. Physical activity-induced proteinuria (which can reach 1-2 g/day) is normalized 1-2 days after exercise and additional kidney dysfunction can be monitored through the calculation of the albumin/creatinine ratio. Therefore, it is useful to have anamnestic information about physical activity over the last $24 \mathrm{~h}$. Different studies estimated the influence of creatine supplements on proteinuria, since they are frequently used during training, and it was concluded that they do not affect it (Taes, Delanghe, Wuyts, van de Voorde, \& Lameire, 2003; Poortmans, \& Francaux, 1999).

Physical activity-induced proteinuria usually appears together with hematuria. Hematuria is defined as a presence of erythrocytes in the urine and can be classified as micro (less than $5 \mathrm{RBC} / \mu \mathrm{l}$ urine) and macro (more than $2500 \mathrm{RBC} / \mu \mathrm{l}$ urine) (Delaney et al., 2001).

In sport, hematuria is classified as traumatic and non-traumatic, depending on the specific sports activities (contact or individual) (Akiboye \& Sharma, 2018). Hematuria induced by running has a prevalence of $20-25 \%$ for a distance of 21-90km (Holmes, Hunt $\&$ Sevier, 2003). Both duration and intensity of physical activity are most important precaution factors that induce hematuria. This hematuria is mainly asymptomatic, with benign clinical course and intact erythrocytes presented in the urine. It is also negative to hemoglobinuria and myoglobinuria. It mainly begins immediately after physical activity and disappears 48-72h after exercise has been finished (Holmes, Hunt \& Sevier, 2003). In the presence of hematuria, it is necessary to exclude other potential factors like urine bladder or urethra injury. If we confirm the presence of intact erythrocytes in the urine and the hematuria passes in the next $72 \mathrm{~h}$, it is not necessary to perform additional diagnostic procedures (Bellinghieri, Savica \& Santoro, 2008).

\section{Physical activity and biomarkers of muscle fatigue and muscle function}

Physical activity increases muscle strength, number of mitochondria, intracellular myoglobin and glycogen concentration as well as tolerance to lactate. If the muscle overcomes its adaptation capacity, muscle fatigue or muscle injury appears.

Decrease in muscle strength during exercise can be regarded as a safety mechanism. If fatigue does not occur or is delayed, structural damage to muscle cells and supportive tissues can occur during the workout. Muscle fatigue and muscle injury are characterized with different biomarkers. There are some biomarkers, like markers of inflammation that can be present in both, fatigue and injury (Finsterer, 2012). 
Biomarkers of peripheral muscle fatigue (BPMF) are classified in accordance with mechanisms underlying muscle fatigue that is, basically deficiency in ATP synthesis, acidosis, oxidative stress and inflammation (Table 2).

Table 2 Biomarkers of muscle fatigue (adopted and modified from Finsterer, 2012)

\begin{tabular}{ll}
\hline Biomarker & Sample \\
\hline Biomarkers of ATP metabolism & \\
- Lactate & Serum \\
- Ammonia & Serum \\
Biomarkers of oxidative stress & Serum \\
Lipid peroxidation & \\
- TBARS & Serum \\
- Izoprostanes & Serum \\
Protein peroxidation & \\
- Carbonyle groups & Serum \\
Antioxidative capacity & \\
- Glutathione & Serum \\
- Glutathione peroxidase & Serum \\
- Catalase & Serum \\
- Total antioxidative capacity & Serum \\
Inflammatory biomarkers & \\
- Leucocytes & Blood \\
- IL-6 & Serum \\
- TNF- $\alpha$ & Serum \\
\hline
\end{tabular}

From all the biomarkers listed in Table 2, in laboratory practice only blood lactate determination has clinical significance because blood lactate concentration during exercise reflects the adaptive state of the muscle.

Lactate is a product of anaerobic glycolysis. After being synthesized in the muscle, it is reused in the liver, where it serves as a substrate for gluconeogenesis (Cori cycle). That way, lactate is involved in the control of glycemia during muscle contraction. The physiological value of blood lactate concentration is less than $1 \mathrm{mmol} / \mathrm{L}$ and this value increases with age and does not differ between the sexes (Skurvydas, Streckis, Mickeviciene, \& Kamandulis, 2006). Blood lactate concentration is one of the most frequently measured parameters during clinical examination as well as during laboratory examination of athletes. While an elevated blood lactate concentration may be indicative of ischemia or hypoxemia, it may also be a "normal" physiological response to physical exertion (Drid, et al., 2015). In well-trained athletes, the peak value of blood lactate is reached during very intensive exercise $\left(70-90 \% \quad \mathrm{VO}_{2} \mathrm{max}\right)$ compared to untrained participants (50-60\% $\mathrm{VO}_{2} \max$ ) (Finsterer, 2012). Lactic acidosis can appear as a result of increased blood lactate concentration which induces a decrease in the blood $\mathrm{pH}$ value. The major reason for this clinical condition may be a liver dysfunction that disturbs the Cori cycle (Robergs, Ghiasvand \& Parker, 2004). Lactic acidosis can additionally induce hypocalcemia and hypomagnesaemia. 
Along with the increase in lactate concentration, ammonia production may dramatically increase during exercise (Calvert, Singh, Greenhaff, Morgan, \& Steiner, 2008) and can be used for muscle fatigue assessment while an increase in hypoxanthine concentration is considered a useful biomarker of metabolic stress and muscle fatigue during physical activity and the rest period (Speranza et al., 2007).

Considering oxidative stress in general, physical activity induces production of reactive oxygen species (ROS) (Margonis et al., 2007) but, at the same time, also induces adequate antioxidative mechanisms (Pedersen, 2007). However at present, laboratory determination of ROS after physical activity has no actual clinical significance.

On the other hand, one of the laboratory biomarkers specific for muscle injury is CK. There are three CK isozymes: in the brain (CK1 or BB), skeletal muscle (CK2 or MM) and heart (CK3 or MB). Reference values for CK are 55- 170 IU/L for men and 30-135 IU/L for women.

Physical activity which is accompanied with sarcolemma injury induces an increase in CK activity. Maximal CK activity has been observed after long trail running (marathon, ultra marathon) or after training with heavy weights (Brancaccio, Maffulli \& Limongelli, 2007).

Total CK activity is significantly elevated $24 \mathrm{~h}$ after exercise and can persist elevated for $48 \mathrm{~h}$, during the rest period. This increase in CK activity is usually lower in welltrained than untrained persons and can reach values that are 10-20 times higher than the reference range. Type of training affects $\mathrm{CK}$ activity in a different manner. After eccentric training, maximal $\mathrm{CK}$ values are reached $96 \mathrm{~h}$ after training while high intensity exercise (e.g. football, 2 times/day) leads to a significant $\mathrm{CK}$ increase after 4 days and is normalized between 4-10 days after training (Latham, Campbell, \& Nichos, 2008). But, after rhabdomyolysis, $\mathrm{CK}$ activity starts to rise $12 \mathrm{~h}$ after muscle injury, reaches its peak during 1-3 days and is normalized after 3-5 days post-exercise (Kenney et al., 2012). Therefore, it is very useful to measure CK activity in professional athletes at rest and after physical activity having in mind that under physiological conditions, their resting $\mathrm{CK}$ values are higher than in non-trained individuals.

In spite of its origin, muscle recovery cannot be estimated by $\mathrm{CK}$ activity measurement because no correlation has been observed between CK release from the muscle and muscle ability. False positive results of CK activity increase can be obtained during erythrocytes hemolysis, utilization of statins, after intramuscular injection or venipuncture.

If $48 \mathrm{~h}$ after physical activity the CK activity does not reach its basal (reference) range, other diagnostic procedures have to be performed to exclude the potential presence of hyper-CK since it represents a risk factor for myopathies and dystrophies (Brancaccio et al., 2007). Along with CK, it is always useful to determine other biomarkers of cardiac (dis)function (AST and LDH), and to interpret them together with clinical manifestations (e.g. chest pain) and ECG results.

Rhabdomyolysis is a condition in which damaged skeletal muscle breaks down rapidly. Symptoms may include muscle pains, weakness, vomiting, and confusion. There may be tea-colored urine or an irregular heartbeat. Some of the muscle breakdown products, such as the protein myoglobin, are harmful to the kidneys and may lead to kidney failure. Since only $50 \%$ of patients have muscle pain sensations, biochemical analysis are of great importance in the final diagnosis of rhabdomyolysis. Those biochemical parameters include myoglobin and troponin concentration as well as CK, 
aldolase, LDH, ALT and AST activity determination in plasma and urine (Zimmerman \& Shen, 2013). The primary marker of rhabdomyolysis is elevated CK that can be measured in serum. But exercise of high intensity (55\% - 90\% HRmax) can also induce an increase in CK activity equally as in rhabdomyolysis. Therefore, it is recommended to additionally analyze other parameters, more specific for rhabdomyolysis.

One of them is myoglobin, oxygen-carrying pigment of muscle tissues. During myocyte necrosis, myoglobin is released in plasma, like in AMI during cardiomyocyte necrosis. Since its concentration increases even before CK, myoglobin is considered to be an early marker of AMI (Mythili \& Malathi, 2015). Increase in myoglobin plasma concentration can occur after prolonged physical activity. Its concentration starts to rise 1$2 \mathrm{~h}$ from the beginning of, for example, a cycle race and it remains elevated even after $5 \mathrm{~h}$. Its excretion via urine (myoglobinuria) is nephrotoxic since myoglobin tends to accumulate in the tubular system.

Beside myoglobin, troponin, an intracellular protein integral to muscle contraction, can also be released in plasma in case of myocyte cell membrane damage (Shave et al., 2010). A great amount of cardiac troponin $\mathrm{cTnI}$ and $\mathrm{cTnT}$ is bound to myofilaments but $3-8 \%$ is free in cytosol. So, initially, in case of cell membrane damage, troponin is released biphasicaly, first free troponin and after that troponin that is bind to myosin. Beside increased cell membrane permeability, oxidative stress, disturbance in the acidobasic status, cardiomyocyte necrosis and temporarily hypovolemia contribute also to increase in concentration of plasma troponin (O'Hanlon et al., 2010) that exists after intensive physical activity, mostly running (e.g. marathon, triathlon) (Shave et al., 2010).

So, during analysis of increased troponin concentration as the result of physical activity, it is recommended to also measure other biomarkers of muscle injury, such as CK, AST and LDH activity as well as to perform an ECG.

\section{Physical activity and immune system reaction}

Depending on its type and intensity, physical activity can exhibit both pro- or antiinflammatory effect. This anti-inflammatory effect of continuous physical activity is beneficial in pathogenesis of atherosclerosis, diabetes and other chronic diseases and that is why physical activity is considered a new therapeutic approach in the control of local vascular and systemic inflammation in atherosclerosis (Pinto et al., 2012).

This immunomodulatory effect of physical activity is attributed to synthesis and secretion of specific "myokines" as IL-6, IL-8, and IL-15 during muscular contraction together with IL-1 receptor antagonist and soluble tumor necrosis factor receptors, sTNF-R, molecules that exhibit anti-inflammatory activity. Those "myokines" are secreted from the muscle. Despite a large number of different "myokines", IL-6 is considered to be a specific prototype (Huh, 2018). IL-6 changes are most sensitive to physical activity depending on duration, intensity as well as a mass of skeletal muscles engaged in contractions. IL-6 can be also considered to be an injury marker because it is released from damaged muscles that are infiltrated with macrophages (Febbraio \& Pedersen, 2002). Beside changes in IL-6 and other "myokines" concentrations, the only inflammatory marker that is routinely measured in biochemical laboratory is CRP. A marathon race and other intensive exercise program in well-trained athletes significantly increase proinflammatory cytokines production as well as CRP. Many different studies have reported an increase in the leukocyte number, IL-1 and CRP concentrations together with CK 
activity and D dimmer concentration suggesting that cytokines and muscle injury have an important role in inflammatory response. Their values tended to return to the reference range in 2-6 days after the physical activity has ended (Weight, Alexander \& Jacobs, 1991). An increase in CRP concentration was reported $24 \mathrm{~h}$ after a triathlon while it normalized in the next $48 \mathrm{~h}$. Alongside the increased CRP concentration, there is also an increase in cortisone level, leukocyte number and CK activity (Kasapis \& Thompson, 2005).

Contrary to its increase, it was shown that CRP concentration can decrease after continuous physical activity which can, therefore, exhibit an anti-inflammatory effect. This decrease in CRP is not completely understood but it may be even partially explained by increased secretion of anti-inflammatory cytokines (IL-1 receptor antagonists, IL-10, IL-8), decrease in adipose tissue mass (BMI correction) which therefore decreases the production of pro-inflammatory cytokines (Puglisi \& Fernandez, 2008). These changes lead to decreased synthesis of fibrinogen and other proinflammatory mediators in hepatocytes, as well as CRP (Nicklas, You \& Pahor, 2005).

\section{Physical activity and hematological parameters}

Many hematological parameters like the number of erythrocytes, leucocytes, platelets, together with hemoglobin concentration and parameters of iron metabolism are affected by exercise. Those changes can be explained as a direct effect of exercise or as the effect of hemoconcentration resulting from dehydration during exercise.

Erythrocytes are involved in oxygen transport, they are an important buffer system in plasma and they decrease vascular resistance through NO release which leads to vasodilatation (Mairbäurl, 2013). Some authors observed a decrease in number of erythrocytes as well as in hemoglobin $(\mathrm{Hb})$ concentration in well-trained athletes performing different types and intensities of physical activity (Sanchis-Gomar, \& Lippi, 2014). In contrast, others found that the number of erythrocytes is higher in athletes than in nontrained individuals. That can be an effect of stimulated erythropoiesis or dehydration during exercise. Erythropoiesis is stimulated by a hypoxia inducible factor, HIF-2 $\alpha$ that increases erythropoietin production. HIF-2 $\alpha$ synthesis in the kidneys is stimulated during high intensity exercise which causes hypoxia in kidney tissue. In addition, endurance training and/or resistance training stimulates androgen production that also increases erythropoietin synthesis while catecholamine and cortisone stimulate reticulocytes maturation. That way, exercise increases transport capacity for oxygen, that results in better tissue oxygenation, together with increased synthesis of 2,3-diphosphoglycerate (2,3-DPG) which facilitate oxygen release from hemoglobin (Mairbäurl, 2013).

Similarly to the number of erythrocytes, different authors did not reach an agreement about post-exercise changes in $\mathrm{Hb}$ concentration (Sanchis-Gomar, \& Lippi, 2014) possibly due to the different type, duration and intensity of exercise (Sawka, Convertino, Eichner, Schnieder, \& Young, 2000). But in accordance with physiologically accepted explanation of post-exercise increase in number of erythrocytes, the amount of total $\mathrm{Hb}$ $(\mathrm{tHb})$ in well-trained athletes increases and it correlates well with the level of training capacity that increases $\mathrm{VO}_{2}$ max directly (Schmidt \& Prommer, 2008). Since an increase in $\mathrm{tHb}$ comes after increase in erythrocyte number, it seems that a $\mathrm{tHb}$ increase is the result of stimulated erythropoiesis. This explanation is confirmed by increased number of reticulocytes, as a marker of erythropoiesis intensity, 1-2 days after the performed exercise (Mairbäurl, 2013). 
Hematocrit (Hct) is the volume percentage (Vol \%) of red blood cells in the blood. Physical activity can induce short-term and long-term changes in Hct values (Shaskey \& Green, 2000). Short term changes occur during exercise when Hct increases and, possibly, they are a result of dehydration. Long-term changes in Hct are obtained after exercise when blood volume increases while the erythrocyte volume begins to increase a few days afterwards. That result in temporarily decrease in Hct value and this effect is generally known as "sports anaemia".

Leukocytes are blood cells that are involved in immune response. Strenuous exercise typically triggers leukocytosis (Kratz et al., 2002; Lombardi, Ricci, \& Banfi, 2011; Suzuki et al, 2003; Smith, Garbutt, Lopes, \& Pedoe, 2004). Even there is no physiological explanation for that phenomenon, since an increase in leukocyte number is expected in terms of infection and/or inflammation it is believed that it is caused by dehydration (Saito, Kusaka \& Shimada, 2003). Also, leukocytosis can be caused by demargination of WBCs as the result of increased blood flow during exercise, as well as an acute inflammatory response due to tissue injury, and exercise-induced increases in catecholamine and cortisone levels (Kratz et al., 2002; McCarthy, \& Dale, 1988). This laboratory test result should not be mislead with another underlying infectious or inflammatory process, which would be characterized by other indicative clinical findings.

Similarly to observed changes in leukocyte number, physical activity can induce temporarily increase in platelets number (Heber \& Volf, 2015). That phenomenon is also explained by dehydration and chemo concentration or by increased platelets release from spleen and liver. Acute physical activity increases blood coagulability as the result of increased interactions between platelets but also between platelets and leucocytes.

(Aldemir \& Kiliç, 2005)

Iron is microelement necessary for optimal and complete $\mathrm{Hb}$ synthesis. When absorbed, it is transported through the bloodstream bound to protein transferrin, absorbed in the cells by transferrin receptors and stored in cells bound to protein ferritin. So, plasma ferritin represents an indirect marker of the total amount of iron stored in the body. Physical activity exhibits a negative influence on ferritin levels and plasma iron levels because it decreases the ferritin concentration while, in athletes, the expansion of plasma volume and a shift of iron from the bone marrow depot into the liver depot induces an apparent decrease in iron status parameters (Newhouse \& Clement, 1988). Therefore, several studies showed a high incidence of iron deficiency and decreased serum ferritin values in athletes, particularly in runners and cyclists, both male and female (Sanchis-Gomar, \& Lippi, 2014). But some authors reported opposite results with a significant increase in both iron and ferritin concentrations (Sporiš, Vlahović, Trajković, Milanović, \& Madić, 2016). The explanation for this inconsistent conclusion could be possibly the difference in intensity, duration and frequency of physical activity as well as prior characteristics of individuals.

\section{CONCLUSION}

It is clear that physical activity affects different laboratory test results and that the final effect depends on the type, duration, intensity and frequency of exercise practice. Therefore, it is always useful to know if the patient is physically active continuously or 
not, and the duration of the time interval that has passed after specific exercise program up to the blood sampling for laboratory analysis. Furthermore, the information about halflife of analytes and their metabolic pathways will help better interpretation of laboratory test results in view of physical activity as pre-analytical error.

\section{REFERENCES}

Akiboye, R.D., \& Sharma, D.M. (2018). Haematuria in sport: A review. European Urology Focus, S24054569, https://doi.org/ 10.1016/j.euf.2018.02.008.

Albright, A., Franz, M., Hornsby, G., Kriska, A., Marrero, D., Ullrich, I., \& Verity, L.S. (2000). American College of Sports Medicine position stand. Exercise and type 2 diabetes. Medicine \& Science in Sports \& Exercise, 32 (7), 1345-1360.

Aldemir, H., \& Kiliç, N. (2005). The effect of time of day and exercise on platelet functions and plateletneutrophil aggregates in healthy male subjects. Molecular and Cellular Biochemistry, 280 (1-2), 119-124.

Banfi, G., Lombardi, G., Colombini, A., \& Lippi, G. (2010). Bone metabolism markers in sports medicine. Sports Medicine, 40 (8), 697-714.

Bellinghieri, G., Savica, V., \& Santoro, D. (2008). Renal alterations during exercise. Journal of Renal Nutrition, 18 (1), 158-164.

Booth, F.W., Roberts, C.K., \& Laye, M.J. (2012). Lack of exercise is a major cause of chronic diseases. Comprehensive Physiology, 2 (2), 1143-1211.

Brancaccio, P., Maffulli, N., \& Limongelli, F.M. (2007). Creatine kinase monitoring in sport medicine. British Medical Bulletin, 81 (1), 209-230.

Bweir, S., Al-Jarrah, M., Almalty, A.M., Maayah, M., Smirnova, I.V., Novikova, L., \& Stehno-Bittel, L. (2009). Resistance exercise training lowers HbA1c more than aerobic training in adults with type 2 diabetes. Diabetology \& Metabolic Syndrome, 1 (1), 27.

Calles-Escandon, J., Cunningham, J.J., Snyder, P., Jacob, R., Huszar, G., Loke, J., \& Felig, P. (1984). Influence of exercise on urea, creatinine, and 3-methylhistidine excretion in normal human subjects. American Journal of Physiology, (246), E334-E338.

Calvert, L.D., Singh, S.J., Greenhaff, P.L., Morgan, M.D., \& Steiner, M.C. (2008). The plasma ammonia response to cycle exercise in COPD. European Respiratory Journal, 31, 751-758.

Carraro, F., Hartl, W.H., Stuart, C.A., Layman, D.K., Jahoor, F., \& Wolfe, R.R. (1990). Whole body and plasma protein synthesis in exercise and recovery in human subjects. American Journal of Physiology, 258 (5), E821-E831

Caspersen, C.J., Powell, K.E., \& Christenson, G.M. (1985). Physical activity, exercise, and physical fitness: Definitions and distinctions for health-related research. Public Health Reports, 100(2), 126-131.

Crespo, R., Revilla, M., Villa, L.F., Usabiaga, J., Leibar, X., \& Rico, H. (1999). Transient dissociation of bone metabolism induced by high performance exercise: a study in elite marathon runners. Calcified Tissue International, 64 (4), 287-290.

Delaney, P.M., Price, C.P., \& Lamb, J.E. (2001). Kidney function and disease in Tietz fundamentals of clinical chemistry. Ed Saunders, pp. 631-642

Drid, P., Vujkov, S., Drapšin, M., Casals-Vazquez, C., Čuk, S., Stojanović, M.D. (2015). Lactate concentration in Greco-roman wrestlers before and after final matches. Facta Universitatis Series Physical Education and Sport, 13 (2), 161-166.

Duncan, J.J., Gordon, N.F., \& Scott, C.B. (1991). Women walking for health and fitness. How much is enough? Journal of the American Medical Association, 266 (233), 3295-3299.

Durstine, J.L., \& Haskell, W.L. (1994). Effects of exercise training on plasma lipids and lipoproteins. Exercise and Sports Science Reviews, 22 (1), 477-522.

Eriksson, J., Taimela, S., Eriksson, K., Parviainen, S., Peltonen, J., \& Kujala, U. (1997). Resistance training in the treatment of non-insulin-dependent diabetes mellitus. International Journal of Sports Medicine, 18 (4), 242-246.

Febbraio, M.A., \& Pedersen, B.K. (2002). Muscle-derived interleukin-6: Mechanisms for activation and possible biological roles. FASEB J, 16 (11), 1335-1347.

Finsterer, J. (2012). Biomarkers of peripheral muscle fatigue during exercise. BMC Musculoskeletal Disorders, $13(1), 218$.

Foran, S.E., Lewandrowski K.B., \& Kratz, A. (2003). Effects of exercise on laboratory test results. Laboratory Medicine, 34 (10), 736-742. 
Fujimura, R., Ashizawa, N., Watanabe, M., Mukai, N., Amagai, H., Fukubayashi, T., Hayashi, K., Tokuyama, K., \& Suzuki, M. (1997). Effect of resistance exercise training on bone formation and resorption in young male subjects assessed by biomarkers of bone metabolism. Journal of Bone and Mineral Research, 12(4), 656-662.

Hammouda, O., Chtourou, H., Chahed, H., Ferchichi, S., Chaouachi, A., Kallel, C., Miled, A., Chamari, K., \& Souissi, N. (2012). High intensity exercise affects diurnal variation of some biological markers in trained subjects. International Journal of Sports Medicine, 33(11), 886-891.

Heathcote, K.L., Wilson, M.P., Quest, D.W., \& Wilson, T.W. (2009). Prevalence and duration of exercise induced albuminuria in healthy people. Clinical and Investigative Medicine, (32), E261-E265.

Heber, S., \& Volf, I. (2015). Effects of physical (in) activity on platelet function. BioMed Research International, 2015, 165078 .

Holmes, F.C., Hunt, J.J., \& Sevier, T.L. (2003). Renal injury in sport. Current Sports Medicine Reports, 2 (2), 103-109.

Huh, J.Y. (2018). The role of exercise-induced myokines in regulating metabolism. Archives of Pharmacal Research, (41), 14-29.

Jansen, T., \& Daiber, A. (2012). Direct antioxidant properties of bilirubin and biliverdin. Is there a role for biliverdin reductase? Frontiers in Pharmacology, 3, 30.

Kasapis, C., \& Thompson, P.D. (2005). The effects of physical activity on serum C-reactive protein and inflammatory markers: a systematic review. Journal of the American College of Cardiology, 45(10), 1563-1569.

Kenney, K., Landau, M.E., Gonzalez, R. S., Hundertmark, J., O'brien, K., \& Campbell, W.W. (2012). Serum creatine kinase after exercise: drawing the line between physiological response and exertional rhabdomyolysis. Muscle \& Nerve, 45(3), 356-362.

Kratz, A., Lewandrowski, K.B., Siegel, A.J., Chun, K.Y., Flood, J.G., Van Cott, E.M., \& Lee-Lewandrowski, E. (2002). Effect of marathon running on hematologic and biochemical laboratory parameters, including cardiac markers. American Journal of Clinical Pathology, 118(6), 856-863.

Lakka, T.A., \& Salonen, J.T. (1992). Physical activity and serum lipids: a cross-sectional population study in eastern Finnish men. American Journal of Epidemiology, 136(7), 806-818.

Latham, J., Campbell, D., \& Nichols, W. (2008). How much can exercise raise creatine kinase level—and does it matter? Clinical Inquiries, 545-547.

Leclerc, S., Allard, C., Talbot, J., Gauvin, R., \& Bouchard, C. (1985). High density lipoprotein cholesterol, habitual physical activity and physical fitness. Atherosclerosis, 57 (1), 43-51.

Lindheim, S.R., Notelovitz, M., Feldman, E.B., Larsen, S., Khan, F.Y., \& Lobo, R.A. (1994). The independent effects of exercise and estrogen on lipids and lipoproteins in postmenopausal women. Obstetrics and Gynecology, 83(2), 167-172.

Lofthus, D.M., Stevens, S.R., Armstrong, P.W., Granger, C.B., \& Mahaffey, K.W. (2012). Pattern of liver enzyme elevations in acute ST-elevation myocardial infarction. Coronary Artery Disease, 23(1), 22-30.

Lombardi, G., Ricci, C., \& Banfi, G. (2011). Effects of winter swimming on haematological parameters. Biochemia Medica, 21(1), 71-78

Mairbäurl, H. (2013). Red blood cells in sports: effects of exercise and training on oxygen supply by red blood cells. Frontiers in Physiology, (4), 332

Mann, S., Beedie, C., \& Jimenez, A. (2014). Differential effects of aerobic exercise, resistance training and combined exercise modalities on cholesterol and the lipid profile: Review, synthesis and recommendations. Sports Medicine, 44(2), 211-221

Margonis, K., Fatouros, I. G., Jamurtas, A. Z., Nikolaidis, M. G., Douroudos, I., Chatzinikolaou, A., et al. (2007). Oxidative stress biomarkers responses to physical overtraining: implications for diagnosis. Free Radical Biology and Medicine, 43(6), 901-910.

McCarthy, D.A., \& Dale, M.M. (1988). The leucocytosis of exercise. A review and model. Sports Medicine, 6 , 333-363.

Mohseni, M., Silvers, S., McNeil, R., Diehl, N., Vadeboncoeur, T., Taylor, W., et al. (2011). Prevalence of hyponatremia, renal dysfunction, and other electrolyte abnormalities among runners before and after completing a marathon or half marathon. Sports Health, 3(2), 145-151.

Mooradian, A.D. (2009). Dyslipidemia in type 2 diabetes mellitus. Nature Reviews Endocrinology, 5(3), 150-159.

Mythili, S., \& Malathi, N. (2015). Diagnostic markers of acute myocardial infarction. Biomedical Reports, 3(6), 743-748

Najafipour, F., Mobasseri, M., Yavari, A., Nadrian, H., Aliasgarzadeh, A., Mashinchi Abbasi, N., Niafar, M., Houshyar Gharamaleki, J., \& Sadra, V. (2017). Effect of regular exercise training on changes in HbA1c, BMI and VO2max among patients with type 2 diabetes mellitus: an 8-year trial. BMJ Open Diabetes Research \& Care, (5), e000414 
Newhouse, I.J., \& Clement, D.B. (1988). Iron status in athletes. Sports Medicine, 5(6), 337-352.

Nicklas, B.J., You, T., \& Pahor, M. (2005). Behavioural treatments for chronic systemic inflammation: effects of dietary weight loss and exercise training. Canadian Medical Association Journal, 172(9), 1199-1209.

O'Hanlon, R., Wilson, M., Wage, R., Smith, G., Alpendurada, D.F., Wong, J., Dahl, A., Oxborough, D., Godfrey, R., Sharma, S., Roughton, M., George, K., Pennell, J.D., Whyte, G., \& Prasad, K.S. (2010). Research Troponin release following endurance exercise: is inflammation the cause? A cardiovascular magnetic resonance study. Journal of Cardiovascular Magnetic Resonance, 12 (1), 38.

Panteghini, M., \& Bais, R. (2001). Enzymes. In Tietz fundamentals of clinical chemistry, pp. 322-330, Ed Saunders

Pedersen, B.K. (2007). IL-6 signaling in exercise and disease. Biochemical Society Transactions, 35, 1295-1297.

Pettersson, J., Hindorf, U., Persson, P., Bengtsson, T., Malmqvist, U., Werkström, V., \& Ekelund, M. (2008). Muscular exercise can cause highly pathological liver function tests in healthy men. British Journal of Clinical Pharmacology, 65(2), 253-259.

Pinto, A., Di Raimondo. D., Tuttolomondo, A., Buttà, C., Milio, G., \& Licata, G. (2012). Effects of physical exercise on inflammatory markers of atherosclerosis. Current Pharmaceutical Design, 18(28), 4326-4349.

Poortmans, J.R., \& Francaux, M. (1999). Long-term oral creatine supplementation does not impair renal function in healthy athletes. Medicine and Science in Sports and Exercise, 31(8), 1108-1110.

Puglisi, M.J., \& Fernandez, M.L. (2008). Modulation of C-reactive protein, tumor necrosis factor- $\alpha$, and adiponectin by diet, exercise, and weight loss. The Journal of Nutrition, 138(12), 2293-2296.

Richter, E.A., \& Hargreaves, M. (2013). Exercise, GLUT4, and skeletal muscle glucose uptake. Physiological Reviews, 93(3), 993-1017.

Robergs, R.A., Ghiasvand, F., \& Parker, D. (2004). Biochemistry of exercise-induced metabolic acidosis. American Journal of Physiology-Regulatory, Integrative and Comparative Physiology, 287(3), R502-R516.

Rudberg, A., Magnusson, P., Larsson, L., \& Joborn, H. (2000). Serum isoforms of bone alkaline phosphatase increase during physical exercise in women. Calcified Tissue International, 66(5), 342-347.

Saeed, F., Pavan, P.N., Devaki, K., Mahendrakar, L., \& Holley, J.L.(2012). Exercise-induced proteinuria? The Journal of Family Practice, 61, 23-26.

Saito, Y., Kusaka, Y., \& Shimada, M. (2003). Effects of exercise intensity on circulating leukocyte subpopulations. Environmental Health and Preventive Medicine, 8(1), 18-22.

Sanchis-Gomar, F., \& Lippi, G. (2014). Physical activity - an important preanalytical variable. Biochemia Medica, 24(1), 68-79.

Santiago, M.C., Leon, A.S., \& Serfass, R.C. (1995). Failure of 40 weeks of brisk walking to alter blood lipids in normolipidemic women. Canadian Journal of Applied Physiology, 20, 417-428.

Sawka, M.N., Convertino, V.A., Eichner, E.R., Schnieder, S.M., \& Young, A.J. (2000). Blood volume: importance and adaptations to exercise training environmental stresses and trauma/sickness. Medicine \& Science in Sports \& Exercise, 32, 332-348.

Schmidt, W., \& Prommer, N. (2008). Effects of various training modalities on blood volume. Scandinavian Journal of Medicine \& Science in Sports, 18, 57-69.

Sedlak, T.W., Saleh, M., Higginson, D.S., Paul, B.D., Juluri, K.R., \& Snyder, S.H. (2009). Bilirubin and glutathione have complementary antioxidant and cytoprotective roles. Proceedings of the National Academy of Sciences, 106(13), 5171-5176.

Seip, R.L., Moulin, P., Cocke, T., Tall, A., Kohrt, W.M., Mankowitz, K., Semenkovich, C.F., Ostlund, R., \& Schonfeld, G. (1993). Exercise training decreases plasma cholesteryl ester transfer protein. Arteriosclerosis, 13, 1359-1367.

Shaskey, D.J., \& Green, G.A. (2000). Sports haematology. Sports Medicine, 29(1), 27-38.

Shave, R., Baggish, A., George, K., Wood, M., Scharhag, J., Whyte, G., Gaze, D., \& Thompson, P.D. (2010). Exercise-induced cardiac troponin elevation: evidence, mechanisms, and implications. Journal of the American College of Cardiology, 56(3), 169-176.

Sjogren, H.M. (2007). Transaminase levels and vigorous exercise. Gastroenterology \& Hepatology, 3, 913-914.

Skurvydas, A., Streckis, V., Mickeviciene, D., \& Kamandulis, S. (2006). Effect of age on metabolic fatigue and on indirect symptoms of skeletal muscle damage after stretch-shortening exercise. Journal of Sports Medicine and Physical Fitness, 46(3), 431-441.

Smith, J.E., Garbutt, G., Lopes, P., \& Pedoe, D.T. (2004). Effects of prolonged strenuous exercise (marathon running) on biochemical and haematological markers used in the investigation of patients in the emergency department. British Journal of Sports Medicine, 38(3), 292-294.

Spate-Douglass, T., \& Keyser, R.E. (1999). Exercise intensity: its effect on the high-density lipoprotein profile. Archives of Physical Medicine and Rehabilitation, 80(6), 691-695. 
Sporiš G., Vlahović T., Trajković N., Milanović Z., Madić D. (2016). Haematological and iron status following a soccer match. Facta Universitatis Series Physical Education and Sport, (14), 289-295.

Speranza, L., Grilli, A., Patruno, A., Franceschelli, S., Felzani, G., Pesce, M., Vinciguerra, I., De Lutiis, M.A., \& Felaco, M. (2007). Journal of Biological Regulators and Homeostatic Agents, 21(1/2), 23-29.

Suzuki, K., Nakaji, S., Yamada, M., Liu, Q., Kurakake, S., Okamura, N., Kumae, T., Umeda, T., \& Sugawara K. (2003). Impact of a competitive marathon race on systemic cytokine and neutrophil responses. Medicine and Science in Sports and Exercise, 35(2), 348-355.

Swift, D.L., Johannsen, N.M., Earnest, C.P., Blair, S.N., \& Church, T.S. (2012). The effect of different doses of aerobic exercise training on total bilirubin levels. Medicine and Science in Sports and Exercise, 44(4), 569-574.

Taes, Y.E., Delanghe, J.R., Wuyts, B., van de Voorde, J., \& Lameire, N.H. (2003). Creatine supplementation does not affect kidney function in an animal model with pre-existing renal failure. Nephrology Dialysis Transplantation, 18(2), 258-264.

Vanholder, R., Sever, S.M., Erek, E., \& Lameire, N. (2000). Rhabdomyolysis. Journal of the American Society of Nephrology, 11(8), 1553-1561.

Vella, C.A., Kravitz, L., \& Janot, J.M. (2001). A Review of the impact of exercise on cholesterol levels. Idea Health \& Fitness Source, 1-5.

Yavari, A., NajafiPour, F., Asgharzadeh, A.A., Niafr, M., Mobasseri, M., \& Nikou Kheslat, S. (2011). Effects of aerobic training, resistance and combination on glycemic control and cardiovascular risk factors in type 2 diabetic patients. Medical Journal of Tabriz University of Medical Sciences, 33(4), 82-91.

Weibrecht, K., Dayno, M., Darling, C., \& Bird, S.B. (2010). Liver aminotransferases are elevated with rhabdomyolysis in the absence of significant liver injury. Journal of Medical Toxicology, 6(3), 294-300.

Weight, L.M., Alexander, D., \& Jacobs, P. (1991). Strenuous exercise: analogous to the acute-phase response? Clinical Science, 81(5), 677-683.

Ziberna, L., Martelanc, M., Franko, M., \& Passamonti, S. (2016). Bilirubin is an endogenous antioxidant in human vascular endothelial cells. Scientific Reports, 6, 29240.

Zimmerman, J.L., \& Shen, M.C. (2013). Rhabdomyolysis. Chest, 144 (3), 1058-1065.

\section{FIZIČKA AKTIVNOST KAO PREANALITIČKI FAKTOR KOJI UTIČE NA REZULTATE LABORATORIJSKIH TESTOVA}

Poznato je da fizička aktivnost nedvosmisleno ispoljava pozitivan uticaj na smanjenje incidencije mnogih hroničnih nezaraznih bolesti. Međutim fizička aktivnost se danas svrstava u preanalitičke greške koje nastaju prilikom sakupljanja uzorka. Naime, različiti oblici fizičke aktivnosti, kao i različit intenzitet fizičke aktivnosti, u različitoj meri utiču na vrednost različitih biohemijskih parametara. S toga je, prilikom tumačenja laboratorijskih analiza potrebno imati $u$ vidu da li osoba rekreativno ili profesionalno upražnjava fizičku aktivnost, kog intenziteta je bila primenjena fizička aktivnost $i$ koliko vremena je prošlo od fizičke aktivnosti do davanja uzorka za laboratorijsku analizu. Tek, uzimajući u obzir sve navedene podatke, i poznajući biohemijske osobenosti metabolizma odgovarajućih biohemijskih paramerata i njihovu fiziološku dinamiku može se, sa većom pouzdanošču, definisati granica između "fizioloških" $i$ "patoloških" promena laboratorijskih parametara koje nastaju kao rezultat vežbanja, jer je od suštinskog značaja tumačenje dobijenog nalaza na osnovu koga se dalje procenjuje da li je potrebno nastaviti medicinsko ispitivanje. U literaturi postoje brojni podaci o uticaju fizičke aktivnosti na vrednosti laboratorijskih rezultata ali su postojeći rezultati nekonzistentni zbog velikih varijacija u veličini ispitivanog uzorka, primenjenom tipu, dužini trajanja i intenzitetu fizičke aktivnosti kao $i$ uticaja ostalih bioloških $i$ eksprimentalnih varijabli. U ovom radu smo pokušali da prikažemo promene u vrednostima laboratorijskih analiza koje su nastale kao rezultat fizičke aktivnosti i koje se najčešće sreću u praksi i da objasnimo ova promene u skladu sa njihovim biohemijskim, fiziološkim i metaboličkim osobinama.

Ključne reči: fizička aktivnost, biomarkeri, metabolizam, enzimi, laboratorijske analize 